\title{
The Implementation of Parate Executie in Fiduciary Security Based on Applicable Indonesian Laws
}

\author{
Markus Suryoutomo \\ Faculty of Law, University of 17 Agustus 1945 (UNTAG) \\ Semarang, Indonesia
}

\begin{abstract}
Parateex ecutier eferst to a legalright of a creditor to use self-help if the debtor defaults in payment without a court order, but it is merely based on assistance of the Office of State Auctions. The enactment of Law No. 42 of 1999 concerning Fiduciary (hereinafter referred to as "Fiduciary Law") particularly stipulated in Article 15 paragraph (1) is declared with the words "For the Sake of Justice under One Almighty God". The elucidation of Article 15 paragraph (3) emphasizes that one feature of Fiduciary is the ease of execution when the Fiduciary giver is in breach. Therefore, it is deemed necessary to specifically stipulate a regulation on execution of Fiduciary Security byparate executie based on the executorial title. The Fiduciary certificate has the same power as a enforceable court decision that hasa permanent legal force through the parateexecutiebut until today there is no any norm to regulate it.

This research is purposed to conceptualize in the executorial model of Fiduciary Security through parateexecutieby abducting of the executorialmodel of Mortgage Law (hereinafter referred to as "EMML"). Then, the model is departured from concrete legal facts that have not been regulated by any applicable law and analogically constructed to rules of the executorial model of Mortgage Law to be a legal norm of Fiduciary Security with regard to the nature of objects. The applied method of legal research is the method of normative approach armed with the system of "self-explanatory" stated that a norm is a rule or measure of what ought to be (Das Sollen). The result of the executorialmodel of Fiduciary Security is a recommendation to be an applicable regulation concerning parateexecutieof Fiduciary Security.
\end{abstract}

Keywords: parate execution, abduction of Mortgage Law, Fiduciary Security.

\section{INTRODUCTION}

Fiduciary Security has been existed in the legal practice since before the enactment of the Fiduciary law. The establishment of this law was not regulated, particularly in the distinctive law, but it has been known as Fiduciare Eigendomsoverdracht (FEO) or Fiduciary Transfer of Ownership (Fiducia). The Fiducia, the first time, was found through JurisprudentieBierbrouw Arrestor Judicial Precendent of Brewery case on 25 January 1929in the Netherlands. ${ }^{1}$ In Indonesia, the first Fiducia was found in a judicialjudgment of the Supreme Court on 18 August 1932 as known as Arrest B.P.M CLIGNETT. ${ }^{2}$ The Fiduciary Law gives the more legal certainty for Fiducia as an alternatievesecurity. By this law, that it can obtain the need of society in accordance with movable properties, if the pawn agency or fiduciary duty could not be realized. According to the official elucidation of Fiduciary Law is purposed to accommodate the need of society in arranging to securethe law as one of tools to assist business activities and also to obtain the legal protection for stakeholders. By means of FiduciarySecurity, a debtor (fiducia giver) still can hold the quaranteed object to run his business financed by loan through fiducia agreement. Therefore, a creditor needs debtor's trust analysized by the Five of Creditinter aliacharacter, capital, capacity, collateral, and condition of economy.

\footnotetext{
${ }^{1}$ The Dutch Supreme Court has taken the Fiduciary under the pressure of practical requirements in the Judiciaal Judgment of Brewery case and then full accepted. Consequently, the existed fiduciary ownership is stipulated in artikel 3:84 in lien law. See, EvelineGoessens, De HistorischeOorsprong van het Numerus Clausus Beginsel in het Goederenrecht, Jura Falconis, Jg. 47, 2010-2011, nummer 1, p. 184.

${ }^{2}$ Sri Soedewi Masjchun, Hukum Jaminan di Indonesia Pokok-pokok Hukum Jaminandan Jaminan Perorangan, Liberty, Yogyakarta, 1980, p. 74.
} 
Subsequent to the enactment of Fiduciary Law, the binding number of FiduciarySecurity has run into a significant transformation. In other words, it is a binding escalation not only due to the applicability of law but also the behavior of customer and the financial condition. What I mean by the behavior is to meet the legal needs in application for credit guaranteed by FiduciarySecurity. Logically, it can be interpreted that such fluctuation is caused by the needs to have vehicles e.g. cars or motor cycles. The financial condition implies the ability of customers to pay off their debt through FiduciarySecurity.

One alternative option in financing is bank. The legal definition of bank as stipulated in Article 1 point 2 of Law No. 10 of 1998 concerning Amendment of Law No. 7 of 1992 Concerning Banking (hereinafter referred to as "Banking Law") is a corporate entity mobilizing funds from the public in the forms of Deposits and channeling them to the public in the forms of Credit and/or other forms in order to improve the living standards of the common people. In Indonesia,Bank Indonesia (BI) has been strongly influenced by its role and policies due to its position as the national central bank. The Banking Law delegated to it in taking for guidance, control and supervision of all financial institutions. ${ }^{3}$

The function of banking is in collecting and distributing the funds closely related to the general interests, so that the banking is obliged to maintain them very well. The banking must be getting the channeling those to productive sectors to realize the national development goals. ${ }^{4}$ By means of the increasing growth of credit (channeling of credit), many problems emerge simultaneously, even though the percentage is small, but this matter can disturb the healthy banking system. The banks face serious difficulties in execution if their debtors are failured to meet their legal obligation of debt repayment because there is no any applicableregulation. The implementation in executing should be filed a lawsuit in court that the process will spending more time and cost.This problem can be solved by the FiduciarLaw, mainly referring to Article 15.

Article 15 states that paragraph (1) In Fiduciary Certificates referred to in Article 14 paragraph (1) shall include the following words "For the Sake of Justice under One Almighty God"; that paragraph (2) states Fiduciary Certificates referred to in subsection (1) has the same power as a enforceable court decision that hasa permanent legal force; that paragraph (3) declares if the debtor breach the contract, a Fiduciary Receiver has the right to sell the object of Fiduciary on his own behalf. In Elucidation of paragraph (3) of this article declares that one feature of Fiduciary Security is an easy way in the implementation of execution in casuif a Fiduciary Giver is in breach. It is deemed necessary to specifically stipulate a regulation on execution of FiduciarySecuritybyparateexecutie based on the executorial title.

According to Subekti, parateexecutie is to run his own or take himself what he is entitled, in the sense without going through court proceedings judge referred to collaterals to further sell them. ${ }^{5}$ Tartib defines parateexecutieis legal action by the creditor (the holder of security goods such as liens and mortgages) which allows the resale of security goods without going through court proceedings, but throughthe Office of State Auctions. ${ }^{6}$ Hence, it can be understood that the implementation of parateexecutieis an easy and simple way for creditors to reclaim their receivables when their debtors default in payment. This is much better than execution without going through court. Of course, it sets forth comprehensively the implementation of fiduciary security execution as mandated by Article 15 paragraph (3) of Fiduciary Law.

\section{DISCUSSION}

\section{The Implementation of Fiduciary Security Execution beforethe Enactment of Fiduciary Law}

In handling of Non Performing Loans (NPL) executed by creditors, there are various ways which depend on good faith and business circumstance of debtors, as follows:

\footnotetext{
${ }^{3}$ P. S. Srinivas and DjauhariSitorus, The Role of State Owned Banks in Indonesia, paper to be presented at the Brookings/IMF/World Bank conference on "The Role of State-Owned Financial Institutions: Policy and Practice" being held during April 26-27, 2004, at the World Bank, Washington DC. p.6.

${ }^{4}$ Mariam DatuBadrulzaman, Aneka HukumBisnis, Alumni, Bandung, 1994, pp. 105-106.

${ }^{5}$ Subekti, Pelaksanaan Perikatan, Eksekusi Riildan Uang Paksa, Dalam: Penemuan Hukumdan Pemecahan Masalah Hukum, Proyek Pengembangan TeknisY ustisial, MARI, Jakarta, 1990, p. 69.

${ }^{6}$ Tartib, CatatanTentangParateExecutie, in MajalahVariaPeradilanYear. XI, No. 124, January 1999, pp. 149 150.
} 
a. Negotiation. It will be performed by creditors to their debtors having good faith, cooperative, and save business activities. This negotiation is practically created in the form of debt restructuring as the first step to overcome the NPL.

b. Selling. It is under the hands on an agreement between the Fiducia Giver and the Fiducia Receiver. Steps must be taken by creditors in an effort to handle for the arrear of loans as cause of the NPL, as follows: ${ }^{7}$

1) Notification of the late payment of the credit installments shall be done in one day after due date, if a debtor has yet to pay the installment payment. It will then be out the billing statement form the administrative computer on behalf of the debtor. The late payment will be certainty handed over by the administrative credit to the marketing department. Subsequently it will be followed up with a formal notification of the late payment. A letter of the formal notification must be performed one time in the first month. Meanwhile the notification by phone must be done one time in a week for one-month starting form the day of the late payment.

2) Giving warning letter. It shall be executed, if it has been overdue one month from receiving the first warning letter and the debtor has not been showing good faith and cooperative to accomplish his obligation in credit payment. The creditor, then, will send the second warning letter to the debtor. This letter is a sort of a hard warning. By its release, the creditor will put lower the status of the debtor.

\section{The Implementation of Fiduciary Security Execution after the Enactment of Fiduciary Law}

Parateexecutieis an effort beyond the Civil Procedure in Fiduciary Law. The ratio legis of this idea is stipulated particularly on Execution of Fiduciary Security through the parateexecutieinstitution. The term of "parateexecutie" explicitly has never been stated in the legislation. Pursuant to etimology, the term derives from "paraat" means "in the hands", so that it can be said as a tool of execution which is ready at hand. According to legal dictionary, the parateexecutiehas meaning "a direct implementation without going through court proceedings or a decree of judge".

The legal doctrine gives an explanation of the parateexecutiethat the creditor can sellthe securitied object on his own behalf, or if the debtor default in payment, the creditor then can implement to execute it without going through fiat of the Chief of District Court. ${ }^{9}$ The creditor shall not follow "rule of game" regulated by the Civil Procedure - therefore there is a special regulation - no need to seize formerly, no need to involve the bailiff. ${ }^{10}$ Certainly, the procedure is easier and the cost is lower. ${ }^{11}$

The phrase "has right to sell on his own behalf" refers to the term of parateexecutie. On the pawn agency, the parateexecutieis explicitly based on Article 1155 of Indonesian Civil Code that declares:

"Unless the parties otherwise stipulate, in the event that the debtor or the pledgor does not comply with his obligations, the creditor shall be authorized, following the lapse of a specific term or in the event that no specific term was stipulated, after a summons in respect of compliance, to sell the pledge in public pursuant to local customs and in accordance with the usual requirements, to settle the debt which is include the interest and costs incurred from the proceeds of the sale".

This article is not longervalisdbecause the norm of parateexecutiewas referred to Article 15 paragraph (1) of Fiduciary Law.

In Fiducairy Certificates referred to Article 14 paragraph (1) shall include to following words "For the Sake of Justice under One Almighty God". According to paragraph (2) of this article, the Certificates havea same power as enforceable court decision that hasa permanent legal force. The term "enforceable" means directly enforceable without trial and final and binding on the parties to implement the decision. In this regard if the debtor defaults in payment, the creditor as a Fiduciary Receiver has right to sell the object of Fiduciary on his own behalf.

\footnotetext{
${ }^{7}$ Markus Suryoutomo, Laporan Penelitian Dosen Muda : Efektivitas Pelaksanaan Undang-Undang Nomor 42 Tahun 1999 TentangJaminanFidusiaSebagaiAgunanKredit Bank, DirjenDikti, Semarang, 2007, p. 46.

${ }^{8}$ KamusHukum, BahasaBelanda-Indonesia-Inggris, Edisilengkap, Aneka, Semarang, 1977, p. 655.

${ }^{9}$ V.Nerop, Hypotheekrech, TjeenkWillink, Zwolle, 1937, p. 153.

${ }^{10}$ A. Pitlo, Het ZakenrechtNaar Het NederlandsBurgelijkWeboek, TjeenkWillink\& Zoon, Haarlem,1949, p. 498.

${ }^{11}$ Hofmann, Het NederlandsZakenrecht, J.B. Wolters, Groningen - Den Haag - Batavia, 1933, p. 498.
} 
In Elucidation of Article 15 paragraph (3) states that one feature of Fiduciary is the ease of execution when the Fiduciary Giver is in breach. it is deemed necessary to specifically stipulate a regulation on execution of FiduciarySecuritybyparateexecutie based on the executorial title.

Pursuant to Meeuwissen, the legal dogmatic must be firstly aanalytical descriptive means giving analytic and descriptive in accordance with the content and structure of the applicable law. ${ }^{12}$ Secondly,its character is systematic. Moreover, this shall systematize legal events that have been described and analysed. The way is to find the principles which are underlain with those legal events. ${ }^{13}$ Thirdly, the legal dogmatic is tended to hermeneutic. Regarding this case, Meeuwissen proposes necessarily an interpretation to the applicable law. The activity of the interpretation is done in the context of finding a clear, deep definition. ${ }^{14}$ Then, the fourthly character of the legal dogmatic is normative where it must be searching to ratio in accordance with the applicable law. Consequently, he explicitly states that it is not free value. ${ }^{15}$ The last character of the legal dogmatic is practical. This can be removed from its character having the normative value.

Betweentheory and practice should be bridged by the legal dogmatic. Ultimately the dogmatic shall surely be dealing with the practice matters. This notion is used to solve the parateexecutie according to Fiduciary Security by way of abducting the execution of Mortgage Law. Hereby, the analogy is also used to help the construction. That is argumentum per analogiam armed with legal refining (rechtsverfijning), argumentum a contrario, and argumentum a fortiori.

\section{The Executorial Model of Fiduciary Security through ParateExecutie by Abducting of the Executorial Model of Mortgage Law}

Hereitexlplains the procedure of Executorial Model of Mortgage Law that has been performed by the District Court through the assistance of the Office of State Auctions. This procedure is ruled by Article 20 of Mortgage Law. In accordance with the execution of the Encumbrance Right is stipulated in Article 26 of Mortgage Law. It must pay attention for the provision of Article 14 of Mortgage Law declares that the grosse deed of Hypothec is an evidence of the existence of Hypothec, while the Encumbrance Right certificate is an evidence of the existence of Encumbrance Right. As described in point 9 of General Elucidation of Mortgage Law, the transitional provision in this Article confirms, that during the transition period, the above Procedural Law shall be applicable for the execution of Encumbrance Right, with the submission of the Encumbrance Right certificate as a legal basis for the execution.

Article 26 of Mortgage Law and its Elucidation as described above can be understood that the law maker of Mortgage Law had an inclination in the fase of transition, before the existence of a regulation rules the execution of Encumbrance Right, subsequently the execution of hyphotec must follow the execution stipulated by Mortgage Law. Otherwise, by virtue of the provision in Article 14 of Mortgage Law on the execution of hyphotecstill exists to the execution of Mortgage Law as long as no new laws.

According to Article 14 paragraph (3), Encumbrance Right certificate shall have an executorial power equal to the decision of the Head of District Court with a fixed legal force and shall serve as a substitute for the former grosse deed of hypothec as far as land title is concerned. This transitional provision brings a legal consequence that is the provision of the legal procedure is also applicable for Encumbrance Right with the handover of the Encumbrance Right Certificate. ${ }^{16}$ This leads to emerge a legal question whether the hyphotec execution procedure is merely intended to the execution based on the executiorial titile in the Encumbrance Right Certificate or in Article 6 of Mortgage Law.

\footnotetext{
${ }^{12}$ Meeuwissen, Tentang Pengembanan Hukum Ilmu Hukum, Teori Hukum dan Filsafat Hukum, Penerjemah: B. Arief Sidharta, Bandung, Refika Aditama, 2014, p. 44-49.

${ }^{13}$ Ibid.

${ }^{14}$ Ibid.

${ }^{15}$ Ibid.

${ }^{16}$ Sudargo Gautama, KomentarAtasUndang-UndangHakTanggunganBaruTahun 1996 No. 4, Citra AdityaBakti, Bandung, 1996, p. 122.
} 
The existence of an "executorial title" results an executorial provision that is an forced power. ${ }^{17}$ The executorial title on Encumbrance Right Certificatedeclared with the words "For the Sake of Justiceunder One Almighty God" as stipulated in Article 14 paragraph (2) of Mortgage Law shall have an executorial power equal to the decision of the Head of District Court with a fixed legal force and shall serve as a substitute for the former grosse deed of hypothec as far as land title is concerned.

Indeed, based on the executorial title on the Certificate of Encumbrance Right has same procedure as referred to Article 224 H.I.R (Het Herziene Indonesische Reglement) or Article 258 of R.Bg. (Rechtsreglement Buitengewesten). ${ }^{18}$ Thus, the procedure must be followed by the creditor as the holder of the Encumbrance Right shall first submit an application of the stipulation to the Chairman of the District Court in order to issue the seizure of execution over the land object. The execution should be performed by force, even with the help of police officers. After the Chairman of the District Court receive the application of the creditor as the holder of the Encumbrance Right, then he calls the debtor for notification and admonition (aanmaning), so that the debtor meets achievements as agreed upon with the creditor. If the debtor does not meet the call of the chairman and he does not give the right reason, then the process of auction on Encumbrance Right as collateral will be executed.

The process will be executed by the Chief of the Distric Court as auction seller for the interest of the creditor, so that he is entitled to determine the term of conditions of auction for the auction applicant. According to Article 20 paragraph (4) of Mortgage Law, the next step must previously be given an announcement before the auction through a newspaper for two times in a row within a period of 15 days. Before the announcement of auction, the debtor must give an opportunity to pay off debt, fees and interest in accordance with Article 20 paragraph (5) of Mortgage Law and its elucidation. In fact, what occurs all this time, although the auction has been published, if the debtor pays off his debt, fees and interest. Consequently, the auction will be terminated. ${ }^{19}$

On the Certificate of Encumbrance Right as referred to Article 224 H.I.R./258 R.Bg is very different to the process of execution based on Article 6 of Mortgage Law (parate executie). Pursuant to this article, it states that "in the event of Debtor's default, the holder of first Encumbrance Right may sell by virtue of his own authority the Encumbrance Right object in a public auction and collect the settlement of his receivables from the proceeds of such sale". The creditor as the holder of first Encumbrance Right submits the application to the execution of the Office of State Auctions. The first Encumbrance Right to sell the mortgage objectby virtue of his own authorityin a public has been given by law automatically. The authority is not obtainable by the grantor of Encumbrance Right but it has been automatically available to him on the basis of the law has been giving to him. ${ }^{20}$

\section{The Ideal Construction to Overcome Obstacles of the Implementation of the Fiduciary Security ParateExecutie}

The ideal construction to overcoming obstacles of the implementation of the Fiduciary Security ParateExecutie will be enforced through the legal argumentation before going in the direction of the legal formation (rechtsvorming) with the intention of closing the absence of the rule to figure out the intersection in order to obtain the answer of a legal problem solving. The legal argumentation has the form of opinions based on coherences of the applicable laws to solve this legal problem.

\footnotetext{
${ }^{17}$ Setiawan, EksekusiHipotik, Media Notariat, No. 20-21 Year VI, July-October, 1991, p. 69.

${ }^{18}$ Both H.I.R and R.Bg has been applying as procedural law. The H.I.R is the Revised Regulation for Indonesian and applied for Java and Madura. Meawhile the R.Bg is Rules on the administration of Justice in the outer provinces or other islands. These provisions were intended to govern evidence in both court hearings and arbitral references. See, Michael Charle Pryles, Dispute Resolution in Asia, Kluwer Law International, Alphen aan den Rijn, The Netherlands, 2006, see p. 194. According to Daniel S. Lev, Indonesian Judges have nevertherless referred to Burgelijk Rechtsvordering (civil procedure) and Strafvordering (criminal procedure) for the useful rules and procedures not available in the H.I.R. Their ability to do so was facilitated by the adoption of the H.I.R only as a "guide" (pedoman) to procedure, rather than as a binding and permanent code. See, Daniel S. Lev, Legal Evolution and Political Authority in Indonesia: Selected Essays, Kluwer Law International, Dordrecht, The Netherlands, 2000, p. 75.

${ }^{19}$ RetnowulanSutantiodan Iskandar Oeripkartawinata, Hukum Acara Perdata dalam Teori dan Pratek, Mandar Maju, Bandung, 1989, p. 18.

${ }^{20}$ Herowati Poesoko, Dinamika Hukum Parate Executie: Obyek Hak Tanggungan, CV. Aswaja Pressindo, Yogyakarta, 2013, pp. 308-310.
} 
The fiduciarycertificate shall include the words "For the Sake of Justice in the Name of God Almighty" as laid down in Article 14 paragraph (1) of Fiduciary Law. The certificate shall has the same power as a enforceable court decision that hasa permanent legal force (inkracht van gewijsde) stipulated in Article 14 paragraph (2) of Fiduciary Law. Moreover, the execution is set forth in Article 29 paragraph (1) that the execution of Fiduciary Law without going through the court proceedings in foreclosing and auction, and the assistance of the authorities. Consequently, the certificate gives the legal force for the Fiduciary Receiver or creditor to perform the execution of the fiduciary object in the hand of the Fiduciary Giver.

If the execution of Fiduciary Security is against the security object from a defaulting debtorhas successfully been seized and as soon as possible to be conducted the auction by the creditor. The provision of legal norm on breach of contract (default) laid down in Article 1243 of Indonesian Civil Code regulates the replacement of costs (kosten), losses (schaden) and interests (interessen) because the debtor has been failure to fulfill a loan of agreement. This is more specifically stipulated in Article 7 of Fiduciary Law and reaffirmed in Article 34 of Fiduciary Law that states: 1) If proceeds of the execution exceed the value of the guarantee, the Fiduciary receiver shall refund the excess to the Fiduciary giver; 2) If proceeds of the execution are not sufficient for the repayment of the debt, the debtor remains responsible for the unpaid portion of the debt.

The replacement of costs, losses and interests becomes the obligation that must be met by the debtor to the creditor. This norm reflects the right to reposses of fiduciary object owned by the creditor, but it couldbe specifically and detaily asserted in the contract by the parties concerning matters relating to event of defaults. The Fiduciary receiver in its position and capacity as legal owner act to takethe authorization of fiduciary object from the Fiduciary giver in its position and capacity as economic owner on fiduciary object. ${ }^{21}$ Thus, the Fiduciary receiver is entitled to the principle debt, interest and cost which has been paid by him through the seizure and then the followed up by the auction.

\section{Execution of Fiduciary Security by Assistance of the Authority}

In fact, execution of FiduciarySecurity by assistance of the authority to do the seizure is not the nature of Fiduciar Law because it requires much cost. Consequently, many financial institutions do not use the procedures stipulated by legal norm but for instance they hire unofficial debt collectors to expedite the recall of fiduciary object from the hand of a good will debtor. In this regard, their capacity as creditor can hire the service of official debt collector from the Debt Collection Agency Service.

The notion to hire the Debt Collection Agency Service refers to Circular Letter of Central Bank Number: 14/20/DPNP/2012 date July 27, 2012 concerningPrudential Principles for Commercial Banks Outsourcing Partial Job Implementation to Other Parties. Nevertheless, to ensure security and order, debtors should ask for assistance of the authorities such as county court bailiff and police.The safeguard for execution is act of police in order to provide security and protection to the execution implementation based on Article 2 of Regulation of the Chief of the Indonesian National Police Number 8 of 2009 regarding Securing Execution of Fiduciary Security.

The implementation of Fiduciary Security execution disembogues into the auction both the execution is performed by the creditor self according to Fiduciary Law byway of voluntary or reconciliation, and the court disposal armed with or without imprisonment for civil debts (paksa badan/gijzeling) unless direct sale with the agreement of both the Fiduciary giver and receiver if thereby the highest price is obtainable to the benefit of the parties. ${ }^{22}$ The auction must follow the procedure as stipulated in Article 15 paragraph (2) of Fiduciary Law.

\footnotetext{
${ }^{21}$ Ibid.

${ }^{22}$ The Imprisonment for civil debts is regulated by Supreme Court Regulation No. 1 of 2000 concerning Institution of Imprisonment for Civil Debts. This imprisoment is an indirect effort by entering a debtor's bad faith into the State Prison stipulated by Court, to force him fulfilling his obligations. Debtor's bad faith is an debtor, guarantor or warrantor of debt who is able to pay his debts but he will not meet his obligationsfor at least Rp. 1 billion (or approximately USD 100.000). It can not be charged against the debtorwho was aged 75 years. It can be provided for for 6 (six) months and can be renewed in every six (6) monthswith a maximum of three (3) years.
} 
The auction shall be performed through general auction by the Office of State Auctions. The creditor is entitled to take the repayment from the sale proceeds by the way of the exclusion of other creditors or concurrent creditors based on aprior rightruled by Article 27 of Fiduciary Law. This article emphasizesnamely firstthe fiduciary has precedence over othercreditors. Second, the right that takes precedence is the right of the Fiduciary receiver to settle their claims against the proceeds of execution of the Fiduciary object. Third, the right of precedence of the Fiduciary receiver is not discharged due to the bankruptcy and liquidation of the Fiduciary giver.

The recent regulation is refer toFinance Minister Decision Number: 304/KMK.01/2002 concerning Instruction of Auction Official dated June 13, 2002, particularly stipulated in Article 2 paragraph (3) states that "the State of Auction may not refures a auction which is inteded to him if all requirements has been fulfilled". Moreover, the Decision is followed up with the Decision of Direktur General of State of Auction Number:35/PL/2002, regarding Technical Instruction of Auction Implementation dated September 27, 2002, on chapter I Article 3 point 8 declares that the requirements of specifuc auction is based on Article 29 of Fiduciary Law.

According to several laws that has been mentioned above, increasingly clear that the implementation of creditor's right by auction shall be executed by the State of Auction. The next legal issue whether Fiducia giver will cede the object of fiduciary voluntarily in order to the implementation execution of Fiduciary. It should be here emphasized that the object of Fiduciary Security is one of the real execution which means if the object does not exist having a consequence that the implementation of aution is null.

\section{Ratio Legisof ParateExecutionInstitution of Fiduciary Security}

Based on the research, the Executorial Model of Fiduciary Security often failed in practices not only caused by the deed of bad faith debtors but also there is not applicable legal norms. That act can be certainly controlled if there are such laws concerning on the executorial model. Those problems are very detrimental to the financial institutions as creditors. If the credit crunch, consequently many banks will go bankrupt due to they can be collecting and distributing funds.

Actually above circumstances undergone by creditors are on the contrary to the nature of the law. According to Jaap C. Hage, law is technique to control the behavior patterns of human being (het recht is alstechniekom het gedrag van menstesturen $)^{23}$ thus leading to the order situation is peaceful and prosperous as legal purpose. Therefore, the deed of bad faith debtors could be categorized asimmoral act that violates the right of others namely creditors as well as the basis of consideration of Supreme Court Regulation No. 1 of 2000 concerning Institution of Imprisonment for Civil Debts.

The law should provide justice for creditors to regain their right. The right is something that must be obtained after one fulfills the obligation. The right of creditors is to regain their money after they fulfill their obligation to give such funds to debtors. That what it means by the justice refering to Ulpianus's definiton of justice "justitiaestperpetua et contains voluntas jus suumcuiquetribuendi" mean the justice is the steady and enduring will to render everyone his right". 24

Dworkin suggestedthat there is a legal protection to individual rights of the minority which sometimes are contrasted with the policy of goverment and advocated unwillingness to protect their rights. ${ }^{25}$ This is a reflection of the lack of seriousness in implementing a state-wheel towards a peaceful and prosperous. The obligation of stake holders, in casu by government, is to provide a legal norm as law in implementing Article 29 of Fiduciary Law.From the above statements, something that is absolutely necessary that the government shall immediately make a law to implement the parate executie of Fiduciary Law. If the goverment does not do it, it does not enforce the law well. As Dworkin said that "If the government does not take rights seriously, then it does not take law seriously either." 6

\footnotetext{
${ }^{23}$ J.C. Hage, De Wereld van het RechtdalamRecht, Vaardig, en Zeker, EenInleiding in het recht, onderredactie van J.C. Hage, vijfdedruk, Den Haag, Boom JuridischeUitgevers, 2010, p. 30.

${ }^{24}$ Peter Mahmud Marzuki, PengantarIlmuHukum, Jakarta, KencanaPrenada Media Group, 2012, p. 121.

${ }^{25}$ Ronald Dworkin, Taking Right Seriously, Cambridge Massachusetts, Harvard University Press, 1978, p. 205. ${ }^{26}$ Ibid.
} 
Inevitably, a short and easy way is often done by the creditors to hire a debt collector. Consequently, the purpose of law is not intended to realize the justice so that it creates peaceful and prosperous, but the chaos in the life of our laws. Every legal norm is violated for obtaining their rights back. As Ulpianus expressed about justice and said "the precepts of right and law are these: to live honorably, not to injure another, to give to every one his own." ${ }^{27}$ At least some of the fundamental values of this philosophically can be regulated in implementation of parate executie of Fiduciary Security or there is a legal norm at the same level as Goverment Regulation or Peraturan Pemerintah(PP) in order to protect creditor's rights from the deed of the bad faith debtors.

The definiton of Goverment Regulation can be found in Article 1 point 5 of Law No. 12 of 2011 regarding Formulation of Regulatory Legislation that is "the rules are set by the President to implement the instruction of higher Rules of in the conduct of govermental power." There are such legal principles as stipulated in Article 5 of LawNo. 12 of 2011 as well as guidelines that must be obeyed to draft regulatorylegislations, namely: a. clear purpose; b. made by proper agency or official; c. match between the types, hierarchy, and the contents; d. can be implemented; e. versatility and result; f. clear formulation; and g. openness. Then Article 6 of Law No. 12 of 2011 emphasizes the material contents of Goverment Regulation should reflect the principles of: a. protection; b. humanity; c. nationality; d. family; e. character of Indonesia; f. unity in diversity; g. fairness; h. equality position in law and government; i. order and the certainly of law; and/or j. balance, match, and harmony. In addition to reflecting those principles, certain Rules may contain other principles in accordance with the field of relevant Rules.

From the point of view of the 1945 Constitution of Republik of Indonesia based on Article 5 paragraph (1), the power making of Goverment Regulation shall be vested in the hand of the President. He shall shall determine the government regulations to expedite the enforcement of laws. It is impossible to stipulate a Goverment Regulation if there was a applicable law. Asshiddiqie explains that the Goverment Regulation is a form of delegated legislation, ${ }^{28}$ whereas according to Maria Farida Indrati S. considers that the delegated legislation in formulation of regulatorylegislation ((delegatie van wetsgevingsbevoegheid) is delegation of authority to form higher legislations to the lower ones, to delegate is either expressly or impliedly shown in the statute. ${ }^{29}$

The Executorial Model of Fiduciary Securityas set forth in Article 1 point 11 of Law No. 12 of 2011 shall be laid down in the form of academic dokuments. By the opening of a loophole from that article, indeed, it emerges an obligation immediately to issue such implementing regulation of Article 29 of Fiduciary Law, even though the obligation is not explicitly written thereof.

The result of this paper can be classified as an academic document to be basic to draft the govermental regulation in accordance with the parate executie of fiduciary law especially to expedite Article 29 of Fiduciary Law. Witnesseth and recitals based on theory of legal drafting, applicable laws and legal practices should be made a goverment regulation regarding Execution of Fiduciary Security to achieve the legal ideal that is justice which brings us in the atmosphere of peaceful and prosperous.

\section{Conclusion}

The Executorial Model of Fiduciary Security is a model building in law as order of Article 29 of Fiduciary Law to execute the objects form the bad faith debtors through the parate execution institution formulated by abducting of the Executorial Model of Mortgage Law analogically. Consequently, rules of Executorial Model of Mortgage Law become the provisons of Fiduciary Law with regard its natural objects.Therefore, the goverment shall create a rule that is a government regulation Execution of Fiduciary Security, thus it is possible developed in making a pledge guarantee driven by private financial institutions.

\footnotetext{
${ }^{27}$ Roscoe Pound, The Ideal Element In Law, Indianapolis, Libery Fund, 2002, p. 160.

${ }^{28}$ JimlyAsshiddiqie, PengantarHukum Tata Negara, Jakarta, Rajawali Press, 2010, p. 173.

29 Maria Farida Indrati S, 2013, IlmuPerundang-undanganJenis, Fungsi, danMateriMuatan, Yogyakarta, Kanisius, p. 56.
} 


\section{REFERENCES}

Asshiddiqie, Jimly, PengantarHukum Tata Negara, Jakarta, Rajawali Press, 2010.

Badrulzaman, Mariam Datu, Aneka HukumBisnis, Alumni, Bandung, 1994.

Dworkin, Ronald, Taking Right Seriously, Cambridge Massachusetts, Harvard University Press, 1978.

Gautama, Sudargo, Komentar Atas Undang-Undang Hak Tanggungan BaruTahun 1996 No. 4, Citra AdityaBakti, Bandung, 1996.

Goessens, Eveline, De HistorischeOorsprong van het NumerusClaususBeginsel in het Goederenrecht, Jura Falconis, Jg. 47, 2010-2011.

Hage,J.C., De Wereldvan hetRechtdalamRecht, Vaardig, en Zeker, EenInleiding in het recht, onderredactie van J.C. Hage, vijfdedruk, Den Haag, Boom JuridischeUitgevers, 2010.

Hofmann, Het NederlandsZakenrecht, J.B. Wolters, Groningen - Den Haag - Batavia, 1933.

Indrati, Maria Farida S, IlmuPerundang-undanganJenis, Fungsi, danMateriMuatan, Yogyakarta, Kanisius, 2013.

KamusHukum, BahasaBelanda-Indonesia-Inggris, Edisilengkap, Aneka, Semarang, 1977.

Lev, Daniel S., Legal Evolution and Political Authority in Indonesia: Selected Essays, Kluwer Law International, Dordrecht, The Netherlands, 2000.

Marzuki, Peter Mahmud, 2012, PengantarIlmuHukum, Jakarta, KencanaPrenada Media Group.

Masjchun, Sri Soedewi, Hukum Jaminan di Indonesia Pokok-pokok Hukum Jaminandan Jaminan Perorangan, Liberty, Yogyakarta, 1980.

Meeuwissen, Tentang Pengembanan Hukum Ilmu Hukum, Teori Hukum dan Filsafat Hukum, Penerjemah: B. Arief Sidharta, Bandung, Refika Aditama, 2014.

Nerop, V.,Hypotheekrech, TjeenkWillink, Zwolle, 1937.

Pitlo,A.,Het ZakenrechtNaar Het NederlandsBurgelijkWeboek, TjeenkWillink\& Zoon, Haarlem, 1949.

Poesoko, Herowati, Dinamika Hukum Parate Executie: Obyek Hak Tanggungan, CV. Aswaja Pressindo, Yogyakarta, 2013.

Pound, Roscoe, The Ideal Element In Law, Indianapolis, Libery Fund, 2002.

Pryles, Michael Charle, Dispute Resolution in Asia, Kluwer Law International, Alphen aan den Rijn, The Netherlands, 2006.

Setiawan, EksekusiHipotik, Media Notariat, No. 20-21 Year VI, July-October 1991.

Srinivas,P. S. and DjauhariSitorus, The Role of State Owned Banks in Indonesia, paper to be presented at the Brookings/IMF/World Bank conference on "The Role of State-Owned Financial Institutions: Policy and Practice", April 26-27, 2004.

Subekti, Pelaksanaan Perikatan, Eksekusi Riildan Uang Paksa, Dalam: Penemuan Hukumdan Pemecahan Masalah Hukum, ProyekPengembanganTeknisYustisial, MARI, Jakarta, 1990.

Suryoutomo, Markus, Laporan Penelitian Dosen Muda : Efektivitas Pelaksanaan Undang-Undang Nomor 42 Tahun 1999 Tentang Jaminan Fidusia Sebagai Agunan Kredit Bank, Dirjen Dikti, Semarang, 2007.

Sutantio, Retnowulan, dan Iskandar Oeripkartawinata, Hukum Acara Perdata dalam Teori dan Pratek, Mandar Maju, Bandung, 1989.

Tartib, CatatanTentangParateExecutie, in MajalahVariaPeradilanYear. XI, No. 124, January 1999.

\section{AUTHOR's BIOGRAPHY}

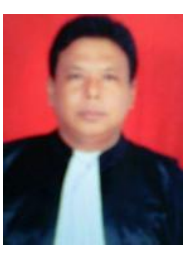

Markus Suryoutomo, S.H, M.Si, Lecture of Faculty of Lawat University of 17 Augustus 1945 (UNTAG) Semarang, Central Java, Indonesia.

Lecture of Civil Law Department: Civil Law Proceeding, Securities Law, Proficiency of Legal Aid, and Ethics of Legal Profession;

Chairman and Attorney at Consultancy and Legal Aid Agency of University of 17 Augustus 1945 (UNTAG) Semarang, Central Java, Indonesia;

Managing Partner at Law Office Markus Suryoutomo and Partners;

Chairman of Profession Advocacy, Branch Executive Council of PERADI (Perhimpunan Advokat Indonesia/Indonesian Advocates Associations) Semarang. 